\title{
Studi Terorisme di Sulawesi Tengah
}

\author{
Muhammad Nur Ali
}

Universitas Tadulako Palu

muhammadnurali24@gmail.com

\begin{abstract}
Poso the center of conflict in Central Sulawesi has been symbiotic to terrorism, so that the critical points of the outside reached at least three border areas. Such as South Sulawesi, Southest Sulawesi, and West Sulawesi. Eventhough, the right answer have not been obtained that weather conflict presents the terrorism or terrorism creates the conflict in Poso, but what appears is that terrorism has formed in Poso. This article focuses on three studies (1) the spirit of ideology, (2) struggle obsession, and (3) network system. The ideological spirit moves the spirit of terrorist in Poso, it is fundamental and radical, the struggle obsession is to transform the established order through delegitimation of goverment power that has causes many anger local terrorist in Poso is not independent because they are realted to extra-local and national terrorist and they even connected to global terrorism network.
\end{abstract}

Abstrak

Poso sebagai titik pusat konflik di Sulawesi Tengah telah bersimbiosis dengan terorisme, sehingga titik rawan luarnya telah meluas menjangkau paling tidak tiga wilayah perbatasan, yakni Sulawesi Selatan, Sulawesi Tenggara, dan Sulawesi Barat. Meskipun belum diperoleh jawaban yang tepat, apakah konflik yang menghadirkan terorisme atau terorisme yang menciptakan konflik di Poso, tetapi yang tampak bahwa habitat terorisme telah terbentuk di Poso. Artikel ini membahas tiga fokus kajian yaitu (1) spirit ideologis, (2) obsesi perjuangan, dan (3) sistem jaringan. Spirit ideologis yang menggerakkan semangat teroris di Poso adalah bersifat fundamental-radikal, dengan obsesi perjuangan adalah untuk mengubah tatanan mapan menggunakan celah delegitimasi kekuasaan pemerintah yang dinilai telah menyebabkan banyaknya kemungkaran. Teroris lokal Poso tidak berdiri sendiri sebab terkait dengan teroris ekstra lokal dan nasional, bahkan menjangkau jejaring terorisme global.

Keywords conflict, the spirit of ideology, struggle obsession, and terrorism network. 


\section{A. Pendahuluan}

Menelusuri peristiwa konflik di Indonesia selama hampir sepuluh tahun terakhir, tampaknya Poso telah menjadi titik pusat konflik di Pulau Sulawesi. Konflik-konflik lokal dan potensi konflik lain khususnya di Sulawesi, merupakan rembesan dan titik rawan luar yang memiliki benang merah dengan konflik yang berpusat di Poso ${ }^{1}$. Konflik di Poso selama ini belum dapat diyakini telah berakhir, sebab salah satu ciri terorisme adalah menciptakan suasana ketakutan berkepanjangan yang mengejutkan dengan tindakan brutal. Ketika semua orang telah merasa aman, peristiwa penembakan seorang tokoh preman kharismatik lintas provinsi yang membuatnya tewas ${ }^{2}$, terjadi pada malam hari tanggal 31 Desember 2009 pukul 21.30. Didugaan bahwa sabotase tersebut dilakukan untuk memancing amukan anggotanya yang tersebar di Sulawesi Selatan, Sulawesi Tenggara, Sulawesi Tengah, dan Sulawesi Barat.

Mengamati peristiwa demi peristiwa di Poso dan wilayah sekitarnya, pada masa jedah dalam hitungan waktu tertentu, jika konflik belum juga "terjadi" oleh dorongan pengalaman aversif para korban, maka peristiwa "diterjadikan" oleh kalangan tertentu" melalui skenario ala teroris. Tindakan-tindakan provokasi, sabotase, peledakan bom, dan sejenisnya yang menimbulkan korban orang-orang tak berdosa dan ketakutan publik yang berkepanjangan, menurut DeNadro (1986), Pruitt \& Rubin (1986), Bandura (1987), Post (2003), Reich (2003), dan Suradji (2005) adalah aksi-aksi yang dapat dikategorikan sebagai tindakan teroris.

Poso dan wilayah sekitarnya telah menjadi arena teroris dengan intensitas yang tergolong tinggi dibandingkan dengan daerah-daerah lain di tanah air. Karakteristik teror yang terjadi selama ini memicu konflikkonflik horisontal dan vertikal. Konflik horisontal bernuansa Suku, Agama, Ras, dan Antar-golongan (SARA) tergelar dengan membenturkan perbedaan yang ada di dalam masyarakat ${ }^{4}$. Sedang konflik vertikal yang

\footnotetext{
1 Misalnya, konflik dan teror yang sering terjadi di wilayah Bungku (Kabupaten Morowali), Lembah Palu, Maranatha, Rante Kala, di wilayah Sulawesi Selatan (Luwu Utara dan Mamasa), dan Sulawesi Barat (Pasangkayu) yang juga telah terindikasi rawan. 2 Andi Alimuddin Page tewas ditembak orang tak dikenal. Menyerupai peristiwaperistiwa sebelumnya, selain untuk menimbulkan ketakutan warga, pelaku berharap adanya reakasi yang dapat menciptakan konflik baru.

3 Mereka yang disinyalir sebagai teroris.

${ }^{4}$ Provokasi untuk memperluas dan memperumit konflik melalui pembenturan perbedaan SARA sering dilakukan, misalnya pengeboman Pura Agung di Poso Pesisir. Melalui peristiwa itu terindikasi bahwa ada upaya untuk menyeret umat dan etnik tertentu yang
} 
bernuansa politik memanfaatkan celah-celah delegitimasi terhadap kekuasaan Bupati sebagai Kepala Daerah dan unsur-unsur pimpinan daerah lainnya, termasuk para wakil rakyat ${ }^{5}$.

Banyak hal yang menimbulkan pertanyaan sehubungan dengan aksi-aksi teroris yang terjadi di Poso dan sekitarnya. Pertanyaanpertanyaan itu antara lain: (1) motivasi apa yang melatari seseorang menjadi teroris dan melakukan aksi-aksi brutal?; (2) faktor-faktor ketahanan apa yang mendukung sehingga terorisme di Poso tetap survive selama hampir sepuluh tahun ini?; (3) mengapa tujuan dan dampak yang menjadi obsesi terorisme dikaburkan oleh para teroris itu sendiri sehingga sulit dipahami?; (4) apa yang menyebabkan para teroris dapat beraksi tanpa perasaan bersalah sedikit pun?; (5) bagaimanakah struktur anatomi dan strategi pengorganisasian terorisme yang begitu rapi sehingga selalu luput dari kontrol pengamanan?; (6) bagaimanakah sistem jaringan terorisme dan jalinan yang menguhubungkan antara teroris lokal dengan teroris yang lebih luas?; dan (7) apa dampak terorisme bagi kalangan masyarakat luas dan pemerintah?. Pertanyaan-pertanyaan tersebut dijadikan titik-tolak menentapkan permasalahan sebagai fokus penelitian, yaitu mengenai (1) spirit ideologis, (2) obsesi perjuangan, dan (3) struktur anatomi dan sistem jaringan terorisme.

Artikel ini bertujuan untuk mendeskripsikan gejala dan fenomena terorisme, khususnya yang berhubungan dengan:

(1) spirit ideologis yang memotivasi seseorang sehingga tergabung dalam kelompok terorisme, mulai dari simpatisan yang ada dalam masyarakat, pendukung pasif, pendudkung aktif, kader aktif, hingga pada pimpinan terorisme atau anggota aktif sebagai teroris yang sesungguhnya.

(2) obsesi perjuangan terorisme dan dampak yang diharapkan oleh teroris, baik kepada pemerintah maupun kepada masyarakat pada umumnya sehubungan dengan aksi-aksi brutal yang dilancarkan.

(3) sistem jaringan terorisme dalam menjalin hubungan antar teroris dan aksi-aksi terorisme yang lebih luas, serta struktur anatomi terorisme yang beroperasi.

selama ini pasif, agar masuk dalam arena konflik seperti umat dan etnik lainnya. Patut disyukuri karena provokasi itu tidak mendapat respon negatif oleh kalangannya.

5 Demonstrasi massal terhadap kekuasaan (konflik vertikal) tidak saja dilakukan oleh awam, tetapi juga oleh PNS Daerah yang sempat melumpuhkan aktivitas layanan publik di Poso. Atas peristiwa itu, bukan mustahil jika jejaring terorisme sudah merasuk ke mana-mana, termasuk ke dalam tubuh PNS. 
Sedangkan kegunaannya adalah sebagai informasi akademik bagi pengembangan ilmu pengetahuan. Selain itu, dapat pula dijadikan sebagai informasi strategis dalam pengambilan kebijakan, khususnya kebijakan deradikalisasi.

Desain penelitian Studi terorisme ini menggunakan rancangan penelitian kualitatif-etnografi. Sesuai dengan tradisi penelitian kualitatif, penjelasan fenomena dilakukan melalui penggunaan logika "induktif abstraktif " yaitu logika yang dijelaskan dari titik tolak "khusus" ke "umum". 6

Empat pendekatan yang digunakan memiliki ruang lingkup untuk mengungkap porsi masalah masing-masing. Pertama, Pendekatan kultural yang dalam perspektif ini memandang budaya sebagai suatu sistem organisasi makna dan sistem adaptasi suatu kelompok masyarakat. Kedua, Pendekatan fenomenologis yaitu pendekatan yang berpandangan bahwa fakta sosial yang tampak di permukaan merupakan gejala atau fenomena yang tersembunyi di dalam benak pelaku. Ketiga, Pendekatan etnometodologis adalah merupakan kelanjutan telaah fenomenologis. Digunakan untuk mendalami gagasan-gagasan dan tindakan-tindakan teroris untuk menemukan kerangka pikir dan asumsi teroris dalam memahami, menafsirkan, dan menyikapi berbagai realitas dalam kerangka "emik". Keempat, Pendekatan interaksi-simbolik dalam hal ini berkaitan dengan tiga premis utama yakni (1) premis yang menjelaskan bahwa teroris bertindak atau beraksi terhadap sasaran-sasarannya sebagai makna yang diberikan oleh fakta, (2) premis yang menjelaskan makna tentang fakta yang diperoleh, dibentuk, dan direvisi dalam proses interaksi sebagai respon dalam kehidupan sehari-hari, dan (3) premis yang menjelaskan pemaknaan fakta oleh teroris secara situasional, atau bagaimana teroris mendefinisikan situasi dan merespon fakta situasional itu.

\section{B. Seputar Terorisme di Indonesia.}

Peristiwa teror yang pertamakali di kenal di Indonesia adalah teror terhadap keluarga Bung Karno yang terjadi pada tanggal 30 November 1957 di jalan Cikini Jakarta, yang kemudian dikenal dengan "Peristiwa Cikini". Setelah berselang sekitar 50 tahun bertepatan dengan transisi tatanan sosial politik pada akhir tahun 1997, aksi-aksi teror yang

\footnotetext{
${ }^{6}$ Sanapiah Faisal , Filosofi dan Akar Tradisi Penelitian Kualitatif, dalam Analisis Data Penelitian Kualitatif, ed. Burhan Bungin., (Jakarta: Rajawali Press, 2003).
} 
memanfaatkan kerentanan masa transisi yang bersimbiosa dengan konflikkonflik dan potensi konflik lokal di berbagai daerah di tanah air, bermunculan ibarat digerakkan oleh sebuah skenario, termasuk di Poso dan wilayah lain di provinsi Sulawesi Tengah. Daerah ini seperti yang terpublikasi secara luas, telah dijadikan sebagai arena aksi para teroris. Aksi peledakan bom yang terkait dengan terorisme di Indonesia selama tahun 1999-2003 yang terekam di Mabes Polri sebanyak 203 kali (Sutanto, 2006). Diperkirakan bahwa wilayah konflik Poso merupakan bagian terbesar dari data peledakan bom secara nasional.

Beberapa daerah telah dijadikan arena oleh teroris seperti Bali, Maluku, dan Poso di provinsi Sulawesi Tengah. Peledakan bom di Pasar Tentena pada Sabtu pagi 28 Mei 2005 (Kompas, 29/5/2005) memakan korban 21 meninggal dan 53 terluka. Bom kedua di Pasar Daging Maesa Kota Palu pada penutupan tahun 2005 tepatnya 31 Desember 2005 pagi, memakan korban 7 orang meninggal di tempat, 50 terluka seirus dan beberapa diantara korban itu kondisinya sangat kritis (Jawa Pos, 1/1/2006). Selain itu, penembakan, penculikan, pembantaian, dan sabotase dengan korban $\leq 10$ orang yang tak terhitung lagi jumlahnya, menambah deretan jumlah korban orang-orang tak bersalah di Sulawesi Tengah. Belum banyak yang diketahui apa sebenarnya target-target yang dikehendaki oleh para pelaku.

Jika ditelusuri lebih jauh, korban-korban konflik Poso yang dalam penelitian ini disebut sebagai "pribadi atau kelompok agresif", mempunyai riwayat aversif akibat terbantai hingga tewasnya puluhan keluarga mereka (lihat: Mengenal Tokoh-Tokoh Kunci Penguasa Tanah Runtuh Poso, 2007). Dalam kaitan itu, Ariyanto Sangadji dari Yayasan Tanah Merdeka Palu pernah mengeluarkan pernyataan bahwa penangkapan seluruh DPO bukan solusi untuk mengakhiri konflik di Poso, sebab setelah itu masih akan muncul DPO-DPO berikutnya ${ }^{8}$. Sarana agresi yang digunakan oleh para teroris jangan diremehkan, karena disamping senjata dan bom rakitan ternyata mereka juga memiliki senjata standar dan

\footnotetext{
7 Banyak diantara orang-orang agresif ini menjadi target DPO dan mereka yang secara konseptual dapat digolongkan sebagai teroris. Hal yang sama juga dikemukakan oleh aparat pengamanan dan pemerintah bahwasanya mereka itu adalah teroris.

8 Pernyataan ini dapat dinterpretasi bahwa dalam masalah ini ada pewarisan kebajikan dan/atau sistem pengkaderan. (Sangadji, 2007)
} 
amunisi yang sekaliber dengan yang digunakan aparat ${ }^{9}$ (lihat misalnya: Baku Tembak di Poso 10 Tewas, 2007). Tampaknya terorisme Poso tidak hanya didorong oleh pengalaman aversif, sebab terdapat gejala telah diintervensi oleh pihak luar yang dikendalikan dari Jawa (lihat: Kelompok Poso Hanya Pelaksana Lapangan, 2007).

Menurut pendapat Bassiouni (1981) evidence yang memakan korban dan menimbulkan ketakutan publik semacam itu dapat digolongkan sebagai aksi terorisme. ${ }^{10}$ Membandingkan dengan aksi terorisme internasional yang mempunyai jejaring global, maka aksi terorisme di Poso belum dapat diprediksi secara jelas. Sebagai contoh, kasus peristiwa terorisme yang tergolong rumit dijejaki adalah kelompok teroris yang pernah melakukan pembunuhan besar-besaran di Lod Airport (Israel). Latar belakang para eksekutor-nya berasal dari Jepang, dilatih di Korea, dipersenjatai oleh Italia, didanai oleh Jerman Barat, dan didukung oleh simpatisan Arab. ${ }^{11}$ Sulit dibayangkan sebab pihak-pihak yang terlibat berasal dari latar belakang ideologi, budaya, dan agama yang sangat berbeda.

Studi yang dilakukan Reich ${ }^{12}$ menyebutkan aksi-aksi teroris selalu terkait dengan delegitimas politiki terhadap kekuasaan pemerintah. Secara lokal, pemerintah Kabupaten Poso yang masih mengahadapi berbagai masalah akibat "protracted conflict", sangat mudah dimanfaatkan oleh teroris untuk menggerakkan massa menyerang kebijakan pemerintah, termasuk tindakan-tindakan berbahaya lainnya seperti peledakan bom dan penembakan misterius. Aksi demo kelompok-kelompok masyarakat, penemuan bom di gedung sekolah, dan di tempat-tempat lain, serta penyitaan/penyerahan senjata dari anggota masyarakat yang tidak berhak masih terus belangsung. Teror bom yang meledak di Pura Agung umat Hindu di desa Toini 10/03/2006 teramati sebagai upaya baru teroris di Poso untuk menyeret umat tertentu masuk ke dalam kancah konflik, karena selama ini yang dibenturkan baru berkisar pada simbol-simbol Islam dan Kristen, serta isu-isu lokal demografis lainnya.

\footnotetext{
9 Temuan senjata dan amunisi dengan kaliber standar ini menguatkan asumsi tentang jejaring luas, sebab mustahil senjata dan amunisi standar itu dapat diproduksi di Sulawesi Tengah khsusnya di Poso.

${ }^{10}$ Reich, W, ed. Origin of Terrorism, terj. Sugeng Haryanto, (Jakarta: Muria Kencana. 2003)

${ }^{11}$ Suradji, Adjie. Terorisme. (Jakarta: Pustaka Sinar Harapan. 2005)

${ }^{12}$ Reich, W, ed. Origin ... 2003)
} 
Post (1984) dalam penelitiannya tentang psikologi teroris, tidak menemukan gejala utama psikopatologi dari para teroris. Demikian pula halnya penelitian yang dilakukan oleh Crenshaw (2003b) tentang karakteristik teroris kelompok terorisme yang bernama National Liberation Front (NLF) di Algeria, menyatakan bahwa pada umumnya teroris adalah orang-orang normal dan memiliki tingkat kecerdasan yang tinggi. Selain itu, Heskin (1984) yang melakukan penelitian terorisme pada anggota Irish Republican Army (IRA) di Irlandia Utara, tidak menemukan indikasi bahwa para teroris memiliki gangguan emosional. Ketiga hasil penelitian yang dikemukakan itu tidak menunjukkan tanda-tanda bahwa seorang teroris mengalamai gejala psikopatologis. Temuan dari hasil-hasil penelitian itu menunjukkan, bahwa seseorang yang tergabung dalam kelompok terorisme atau menjadi teroris adalah mereka yang tergolong berkepribadian normal. Atau dengan kata lain bahwa teroris adalah orangorang yang sadar atas segala tindakan yang dilakukannya.

Dari segi latar belakang sosial teroris, hasil penelitian Clark $^{13}$ terhadap teroris Euzkadi Ta Askatasuna (ETA) di Spanyol mengungkapkan, bahwa pada umumnya mereka berasal dari keluarga marginal atau berketurunan campuran yang sering dilecehkan dalam berbagai aspek kehidupan. Secara sosiologis, isu multikultural sering mengakibatkan sentrisme rasial yang rentan pergolakan karena terkait dengan soal ideologi yang dianut oleh satuan-satuan sosial itu. Hasil penelitian dari berbagai kalangan yang dikumpulkan Reich ${ }^{14}$ menyimpulkan bahwa terorisme yang bernuansa ideologis bukanlah wabah sui generis atau keunikan yang tidak diketahui asalusulnya, bukan juga serangan kemanusiaan yang acak dan tidak dapat dijelaskan, serta bukan pula produk dari orang-orang yang mentalnya kacau.

Melalui pengalaman organisasi Weatherman yang dikemukakan oleh Reich (2003) bahwa proses delegitimasi yang mendasari terbentuknya terorisme ideologis dapat dibedakan dalam tiga tahap, yaitu (1) tahap krisis kepercayaan, (2) konflik legitimasi, dan (3) krisis legitimasi. Setiap tahapan menunjukkan identitas psikopolitik kolektif tertentu yang dicapai oleh suatu kelompok yang termotivasi secara ideologis.

\footnotetext{
${ }^{13}$ Clark, R, 1983, 'Pattern in the Lives of ETA Members;, Journal of Terrorism. Vol.4 No.3: 423-54.

${ }^{14}$ Reich, W, ed. Origin ...
} 
Bertolak dari beberapa hasil penelitian yang diuraikan di muka, tampak bahwa secara ideologis, seseorang atau sekelompok orang dapat terpanggil secara psikilogis dan terdorong secara sosiologis untuk melakukan pergerakan. Mereka itu digolongkan sebagai terorisme ideologis. Partisipasi individu melalui solidaritas kesamaan ideologis berbeda-beda menurut kondisi perseorangan. Ada yang hanya sekadar bersimpati, sebagai pendukung pasif dan aktif, dan ada pula yang menjadi kader, serta sebagai teroris aktif. Obsesi perjuangan mereka sebagai teroris ideologis adalah untuk mewujudkan perubahan tatanan, akan tetapi dampak proses perjuangannya khususnya bagi masyarakat luas pada umumnya sangat merugikan.

Di dalam mewujudkan obsesi perjuangan terorisme, teroris mengorganisir diri secara taktis dan melakukan perluasan jaringan melalui rekruitmen. Secara internasional, organisasi terorisme menurut Suradji (2005) dapat dibedakan dalam tiga kategori, yaitu: (1) Nonstate-Supported Group; (2) State-Supported Groups, dan (3) State-Directed Groups. Motif kategori pertama adalah teroris kelompok kecil yang memiliki kepentingan khusus dan tidak didukung oleh pemerintah, bahkan mereka sangat anti kepada pemerintah. Misalnya, kelompok anti kebijakan pemerintah atau anti korupsi. Kelompok ini biasanya mem"blow-up" permasalahan dalam berbagai bentuk sabotase terhadap kepentingan umum dan sangat membahayakan orang lain yang tak bersalah. Kelompok kategori kedua adalah teroris yang mendapat pelatihan khusus, persenjataan, pasokan logistik, dan dukungan administrasi dari negara asing. Kelompok kategori ketiga adalah teroris yang diorganisir langsung oleh negara, seperti hasil penelitian Seger menyebutkan bahwa pada tahun 1984 Iran mengembangkan sekitar 2.500 personel yang dikenal dengan nama "Special Forces" sebagai sebuah taktis utama dalam rangka penyebaran paham Islam fundamentalis. ${ }^{15}$

Dari segi organisasi terorisme terdapat prinsip-prinsip dasar sebagai citra dan kesetiaan. Pergerakan teroris harus memiliki kepemimpinan yang efektif dan memperoleh dukungan struktur yang luas. Seorang pemimpin harus berdedikasi tinggi terutama kepada organisasi, pengikut, kelompoknya, dan masyarakat luas. Struktur anatomi di dalam organisasi terorisme yang dikenal secara umum, berasal dari "U.S Army" sebagai berikut.

\footnotetext{
${ }^{15}$ Suradji, Adjie.. Terorisme. (Jakarta: Pustaka Sinar Harapan. 2005)
} 


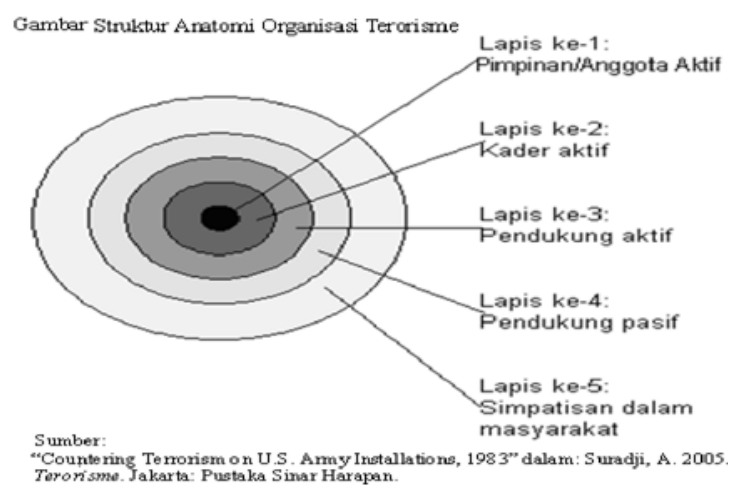

Sistem pelapisan organisasi terorisme terdiri dari lima lapis. Lapis $k e-1$ adalah ketua atau pemimpin pergerakan terorisme, di sekelilingnya adalah para teroris eksekutor yang berdedikasi tinggi. Lapis ke-2 adalah kader aktif, yaitu bagian dari organisasi terorisme yang masih dalam proses pematangan. Kader aktif dipersiapkan untuk melaksanakan tugas-tugas eksekusi pada sasaran-sasaran yang ditargetkan. Lapis ke-3 adalah pendukung aktif, yakni yang melakukan tugas-tugas intelijen dan logistik, serta menjalankan pengumpulan data dan juga dana. Lapis ke-4 adalah pendukung pasif, yaitu pihak yang membantu tugas-tugas pendukung aktif. Kepada mereka sering ditanyai tentang informasi, dimintai logistik dan dana untuk kepentingan kelompok. Dan Lapis ke-5 adalah simpatisan dari kalangan anggota masyarakat.

\section{Studi Terorisme di Sulawesi Tengah}

Hasil penelitian berupa transkrip data terpilih adalah data yang diidentifikasi berdasarkan fokus masalah, yaitu 1) spirit ideology (SI), 2) obsesi perjuangan (OP), 3) sistem jaringan (SJ), dan 4) data lain-lain (LL) yang lebih merupakan selingan teknis saat peneliti mengawali, mengarahkan, dan mengakhiri wawancara. Keempat ragam data tersebut masing-masing terdiri dari data $\mathrm{SI}=113 ; \mathrm{OP}=80 ; \mathrm{SJ}=75$; dan $\mathrm{LL}=41$ dirinci berdasarkan ruang analisis. Jumlah keseluruhan berdasarkan relevansi kegunaannya sebanyak 309 unit data.

Dibandingkan dengan penelitian tahun pertama, pergerakan data adalah dari luar ke dalam sehingga porsi data lebih banyak pada "Lapis Luar ke Dalam”. Pada tahun kedua dilakukan strategi terbalik, penelitian lebih diintensifkan dari dalam ke luar sehingga porsi data lebih didominasi pada "Lapis Dalam ke Luar", dengan maksud untuk memvalidasi data agar 
diperoleh kesesuaian atau perimbangan data melalui pendalaman informasi. Perbandingan data tahun pertama dan tahun kedua dapat dicermati melalui Ikhtisar Data Penelitian berikut.

Tabel Ikhtisar Data Penelitian

\begin{tabular}{|c|c|c|c|c|c|c|}
\hline \multirow{2}{*}{$\begin{array}{l}\text { Data } \\
\text { Fokus } \\
\text { Mlasalah }\end{array}$} & \multicolumn{5}{|c|}{ Ruang Analisis } & \multirow{2}{*}{ Total } \\
\hline & $\begin{array}{l}\text { Lapis } \\
\text { ke-1 }\end{array}$ & $\begin{array}{l}\text { Lapis } \\
\text { ke-2 }\end{array}$ & $\begin{array}{c}\text { Lapis } \\
\text { ke-3 }\end{array}$ & $\begin{array}{l}\text { Lapis } \\
\text { ke-4 }\end{array}$ & $\begin{array}{l}\text { Lapis } \\
\text { ke-5 }\end{array}$ & \\
\hline Masalah-1 & $\begin{array}{l}34 \\
70\end{array}$ & $\begin{array}{l}33 \\
76\end{array}$ & $\begin{array}{l}17 \\
14\end{array}$ & $\begin{array}{l}17 \\
33\end{array}$ & $\begin{array}{l}12 \\
35\end{array}$ & $\begin{array}{l}113 \\
708\end{array}$ \\
\hline Masalah-2 & $\begin{array}{l}16 \\
70\end{array}$ & $\begin{array}{l}22 \\
72\end{array}$ & $\begin{array}{l}11 \\
75\end{array}$ & $\begin{array}{l}18 \\
27\end{array}$ & $\begin{array}{l}13 \\
76\end{array}$ & $\begin{array}{l}80 \\
74\end{array}$ \\
\hline Masalah-3 & $\begin{array}{r}13 \\
4\end{array}$ & 9 & $\begin{array}{l}28 \\
27\end{array}$ & $\begin{array}{r}20 \\
9\end{array}$ & $\begin{array}{r}5 \\
73\end{array}$ & $\begin{array}{l}75 \\
66\end{array}$ \\
\hline Data lain-lain & $\begin{array}{r}13 \\
7\end{array}$ & $\begin{array}{l}8 \\
8\end{array}$ & $\begin{array}{l}5 \\
6\end{array}$ & $\begin{array}{r}8 \\
12\end{array}$ & $\begin{array}{l}7 \\
73\end{array}$ & $\begin{array}{l}41 \\
46\end{array}$ \\
\hline Total & $\begin{array}{l}76 \\
37\end{array}$ & $\begin{array}{l}72 \\
49\end{array}$ & $\begin{array}{l}61 \\
62\end{array}$ & $\begin{array}{l}63 \\
75\end{array}$ & $\begin{array}{l}37 \\
77\end{array}$ & $\begin{array}{l}309 \\
294\end{array}$ \\
\hline
\end{tabular}

Keterangam

Angka yang dicetak mining adalah ragam data tahun pertama.

Pembahasan artikel ini mengacu pada dua hal pokok, yakni fokus dan konteks. Tiap-tiap domain fokus masalah sebagai isu penelitian, dianalisis terkait dan terintegrasi dengan konteks ruang analisis. Pembahasan yang dikembangkan secara lintas-situs mengacu pada tiga isu pokok yang dikaitkan dengan masing-masing ruang analisis untuk menghasilkan sintesis ideografis tiap-tiap lapisan teroris.

\section{Spirit Ideologis}

Penghayatan mendalam terhadap sebuah ajaran tentang apa saja, dapat menggerakkan proses internal dalam diri individu secara psikologik. Proses internal dalam diri individu yang bergerak secara psikologik di nuansakan ke dalam dimensi pengalaman spiritual, sehingga tindakan (kekerasan), efek (merusak/merugikan), dan sasaran kekerasan (korban) diberi justifikasi ${ }^{\mathbf{1 6}}$ untuk mendapat penguatan. Mekanisme pergerakan psikososiologis melalui tahapan sebagai berikut:

\footnotetext{
${ }^{16}$ Antara lain yang sering digunakan di kalangan teroris untuk mengukuhkan tindakannya adalah "amar ma'ruf nahi mungkar; mujahid; syahid; syhada". Sedangkan untuk merendahkan martabat sasaran/ korban digunakan istilah "syethan; dajjal; thogut; kafir; dan yahudi'.
} 
(a) pergerakan dari tindakan "tercela" menjadi "terpuji" dilakukan dengan cara (i) pembenaran moral; (ii) perbandingan yang meringankan; dan (iii) labeling yang menghaluskan.

(b) pergerakan efek "merusak/merugikan" menjadi "konstruktif/ menguntungkan" melalui cara (i) pengabaian akibat; (ii) peminimalan akibat; dan (iii) penafsiran ulang segala konsekuensi - menjadi sesuatu yang wajib.

(c) pergerakan sasaran/korban dari "hak eksistensi" menjadi "pihak yang pantas/wajib menjadi korban" dilakukan melalui (i) dehumanisasi; (ii) deprivatisasi; dan (iii) sebagai pelemparan kesalahan.

Ketiga tahap mekanisme pergerakan psikososiologis tersebut dalam setiap evidence dibungkus dengan "pengalihan" dan "penyebaran" tanggung jawab khususnya kepada pemerintah lokal dan seluruh jajaran pemerintahan nasional.

Spirit ideologis terorisme diabstraksikan melalui proses pengkondisian semangat (conditioning of spirit). Mula-mula yang disentuh adalah aspek-aspek fundamental terutama religiusitas dan belief kultural. Kedua aspek itu ditemukan pada individu teroris di Poso. Substansi ideologis yang menggerakkan semangat para teroris (spirit ideologis) adalah Pertama, berawal dari realitas sosial yang dinilai telah membelenggu hak-hak mereka dan masyarakat secara keseluruhan untuk memperoleh kehidupan yang wajar, terutama dalam bidang keadilan dan kesejahteraan ekonomi, melahirkan stigma buruk seperti korupsi, kolusi, nepotisme, dzalim, dajjal, syetan, garong dan seterusnya kepada oknum dan penguasa. Ciri utama realitas sosial ini adalah delegitimasi terhadap kekuasaan pemerintah yang sah. Kedua, disemaikannya faham-faham baru atau faham pembaharuan atas nama religiusitas agama dengan mengusung semboyan menegakkan agama Allah, atas ridho Allah, memerangi kemungkaran dan syetan, mati sebagai syuhada dan seterusnya yang sangat provokatif. Serangkaian kalimat semboyan provokatif itu di satu sisi menempatkan para pejuangnya ${ }^{17}$ pada posisi yang paling benar dan berada di jalan Allah serta baginya adalah syurga yang kekal. Teroris menanamkan kebencian yang sangat keji kepada (1) individu penguasa dan kroni-kroninya; (2)

17 Dalam hal ini adalah subjek teroris atau individu-individu calon teroris dalam masyarakat. 
perendahkan derajat semua orang baik terhadap orang yang dinilai terkait langsung dengan kekuasaan maupun terhadap orang-orang yang hanya menjadi korban dari operasi gerakan terorisme; dan (3) proses yang menandai penyebaran dan pemakluman faham ini adalah deprivasi dan dehumanisasi. Ketiga, penggembosan terhadap tatanan mapan dan kekuasaan formal pemerintah dengan memasuki dimensi kehidupan politik sebagai kelompok oposisi liar dan tersamar atau terselubung. Resistensi terhadap tatanan mapan yang berlaku disertai dengan alternatif yang sangat utopis, misalnya hayalan tentang tatanan "baldatun toyyibatun warobbun ghofur" sebuah tata kehidupan yang sepenuhnya atas ridho Allah. Evidence yang membuktikan adanya penggembosan terhadap politik dan kekeasaan tersebut adalah tindak kekerasan melalui agitasi dan agresi (cara ala teroris).

\section{Obsesi Perjuangan}

Salah satu sintesis yang dipetik dari pembahasan terdahulu tentang spirit ideologi teroris di Poso adalah adanya pemaksaan untuk merasionalisasikan sesuatu yang tidak rasional. Dalam kaitan ini, teroris terjebak dalam psiko-logika dengan keyakinan yang sangat kuat untuk menggapai ilusi yang telah mengkristal di dalam benaknya. Dapat dikatakan bahwa teroris adalah individu ilusionis, yang pada dasarnya tidak memiliki posisi $\operatorname{tawar}^{\mathbf{1 8}}$ atas keberhasilan perjuangannya mana kala ia dan kelompoknya berhasil. Oleh sebab itu di dalam proses logika mereka selalu diorientasikan pada metakognisi, yaitu bentuk penalaran yang lebih mengedepankan emosi dari pada rasio dalam mengaktualisasikan faham fundamental yang sudah disemai terlebih dahulu. Melalui proses inilah sehingga dalam diri teroris terdapat obsesi, yaitu bayangan psikologis fantastis yang mengharuskannya berjuang ${ }^{19}$.

Menurut anggapan teroris bahwa pemerintah yang berkuasa harus bertanggung jawab atas segala kemungkaran yang menyertai

\footnotetext{
18 Dengan menggunakan logika sederhana bahwa teroris tidak lebih dari kayu api yang siap dibakar. Bagi mereka hanya ada dua kemungkinan tapi bukan pilihan, yaitu jadi abu atau arang.

19 Agar teroris menjadi heroik, istilah "berjuang" atau "perjuangan" dalam terorisme diberi nuansa fundamental menjadi "syuhada".
} 
penderitaan ummat ${ }^{20}$. Cara-cara revolusioner melalui tindak kekerasan dianggap sebagai cara efektif untuk mewujudkan obsesinya yaitu (1) tata kehidupan yang lebih baik menurut klaim kelompoknya, dan (2) menjadi penghuni syurga yang kekal karena syahid atau terbunuh dalam melakukan kekerasan.

Melacak obsesi perjuangan teroris melalui pencermatan terhadap ide-ide dan sepak terjang perjuangannya dalam perspektif interaksi simbolik, terkait dengan serangkaian manipulasi terhadap makna-makna berikut. Pertama, tindak kekerasan teroris yang beraksi terhadap sasaran-sasarannya yang menimbulkan korban orang-orang tak berdosa, digerakkan oleh kekuatan-kekuatan manipulatif terhadap hak azasi orang lain sebagai calon korban menjadi sebuah kewajaran untuk dikorbankan ${ }^{21}$ melalui proses dehumanisasi. Sedangkan terhadap sejumlah person yang sudah tercatat sebagai target ${ }^{22}$ telah diberi stigma perendahan martabat secara total melalui proses deprivatisasi.

Kedua, aksi teroris di Poso juga tidak terlepas dari upayanya terus-menerus mengdiskreditkan sejumlah pejabat lokal berdasarkan pengalaman empirik mereka bahwa pejabat lebih mengutamakan kepentingan diri dan keluarga beserta kelompoknya (KKN) dari pada kepentingan masyarakat umum. Isu ini memang sangat sensitif karena saat itu bertepatan dengan puncak krisis ekonomi. Anggapan tentang kesewenangan pejabat-pejabat lokal tertentu dan penderitaan rakyat yang terhimpit oleh kesulitan ekonomi, diopinikan seolah-olah merupakan fakta yang secara keseluruhan benar, selanjutnya dibentuk menjadi sumber inspirasi bagi upaya-upaya untuk melakukan perubahan, kemudian direvisi dalam proses-proses interaksi sebagai sebuah titik-tolak perjuangan untuk memperoleh legitimasi ${ }^{\mathbf{2 3}}$ dalam melakukan perlawanan terhadap kemapanan.

\footnotetext{
${ }^{20}$ Di dalam wawancara, kata "pemerintah" yang sering digunakan oleh informan tidak ditautkan secara konotatif dengan kata "rakyat", melainkan dengan kata "ummat".

${ }^{21}$ Korban tak berdosa dianggap sebagai konsekuensi dari perjuangan, membunuh atau mengorbankan mereka adalah wajar dan bukan dosa. Pada substansinya, konflik Poso bukanlah konflik komunal, melainkan sebuah arena aksi teroris yang telah membenturkan nilai-nilai perbedaan antar komunitas local yang heterogen.

${ }^{22}$ Pada umumnya operasi terhadap target-target personal tersebut gagal tereksekusi dan lagi-lagi menimbulkan korban orang-orang tak berdosa.

${ }^{23}$ Legitimasi dalam hal ini tidak autentik, melainkan hasil manipulasi sebagai sarana indoktrinasi internal dalam kelompok teroris.
} 
Ketiga, bersamaan dengan penguatan legitimasi internal yang dilakukan dalam kelompoknya, teroris mendelegitimasi kekuasaan pemerintah yang notabene dijalankan oleh oknum pejabat yang sebelumnya telah dideprivatisasi. Dengan memperalat simbol-simbol religius atas nama Tuhan, seolah-olah prakarsa mereka secara mutlak benar dan apabila tidak dijalankan adalah dosa. Manipulasi simbol legitimasi kekuasaan teroris di Poso diduga telah merasuk ke tubuh Pegawai Negeri Sipil (PNS) dan berhasil mencapai puncaknya dengan menggelar demonstrasi yang tergolong besar ${ }^{24}$. Keterpurukan daerah akibat konflik di mana teroris andil di dalamnya kemudian dibumbuhi dengan keterhimpitan ekonomi akibat krisis dijadikan pijakan bagi sebuah definisi situasi untuk membangkitkan respons situasional dalam bentuk perlawanan-perlawanan terhadap kekuasaan pemerintah.

Dengan demikian, obsesi perjuangan teroris di Poso, seperti kelompok-kelompok teroris di tempat lain hanyalah merupakan fatamorgana. Oleh karena teroris di Poso merupakan mata-rantai dari jejaring teroris yang lebih besar, maka jawaban atas kondisi yang diinginkan oleh teroris tersebut ada di sana. Pada kelompok teroris di Poso yang hanya dapat digolongkan sebagai eksekutor lokal, semangat perjuangannya bersifat fundamental (ekstrimis kanan) dengan obsesi kelak akan menjadi mahluk-mahluk penghuni syurga.

\section{Sistem Jaringan}

Dari nama yang disandang oleh kelompok pergerakan yang mengandalkan kekerasan yakni "teroris", maka asosiasi berpikir kebanyakan orang tertuju pada suatu kelompok yang dijalankan dan dikendalikan secara sangat rahasia. Mungkin di sekitar kita atau diantara kita ada teroris, mereka ada di situ dan melakukan aktivitasnya tanpa diketahui oleh siapapun juga. Terorisme memang mempunyai sistem jaringan yang sangat kompleks dan rumit agar tidak mudah terpantau. Tindak kekerasannya berbeda dengan kriminal biasa. Terorisme dapat digolongkan sebagai bukan kriminal biasa (extra ordinary crime).

\footnotetext{
${ }^{24}$ Dari salah satu sumber di lapangan menyatakan bahwa pada pertengahan tahun 2006 telah terjadi demonstrasi besar-besaran terhadap penyelenggaraan kekuasaan pemerintah oleh Bupati Piet Ingkiriwang dan wakilnya Abd. Muthalib Rimi yang melibatkan sebagian besar PNS Daerah. Akibatnya, layanan pemerintah pada saat itu lumpuh.
} 
Membahas tentang jaringan terorisme di Poso dan Sulawesi Tengah pada umumnya, tidak dapat mengabaikan peristiwa konflik Poso sebagai titik tolaknya. Konflik Poso dan terorisme ibarat dua sisi mata uang. Teroris beraksi melahirkan konflik di Poso dan konflik yang tergelar menciptakan habitat bagi teroris. Dari peristiwa 25 Desember 1998 yang memicu konflik besar di Poso, mencetus arena bagi kelompok teroris. Peran orang-orang misterius ${ }^{\mathbf{2 5}}$ sangat menonjol kala itu, yakni saat konflik terbuka selama lima episode dalam kurun Desember 1998 - Desember 2001. Setelah episode perang terbuka selama tiga tahun, pergerakan terorisme berlangsung secara tertutup terutama melalui, penculikan, pemboman, dan sabotase hingga tahun 2006. Meskipun saat ini resistensi penduduk terhadap gerakan provokasi sudah tercipta, namun belum dapat dikatakan secara pasti bahwa Poso telah aman seperti sedia kala, sebab ideide cerdas kelompok teroris sangat sulit terdeteksi.

Mengacu pada sistem pelapisan menurut US Army Intstallation (lihat Gambar 2), secara kontekstual jaringan terorisme Poso dapat dibedakan ke dalam konteks jejaring lokal dan ekstra lokal. Interaksi antar teroris terjalin sangat rahasia, tidak hanya bagi orang luar, tetapi diantara mereka pun acap kali tidak saling kenal dan tidak saling tahu profesi atau peran sesungguhnya yang dijalankan dalam sistem itu. Kalaupun ada salah seorang diantara mereka yang tahu, tetapi diantara mereka tidak saling tahu secara sangat detil. Di dalam jejaring lokal ini secara person semua anggota dalam kelompok teroris saling kenal, tetapi umumnya mereka hanya sebagai bagian dari jamaah yang sering ikut pengajian atau acaraacara silaturrahmi dan diskusi bersama. Hanya sebagian kecil diantara mereka yang saling tahu tentang peran masing-masing. Mereka itu adalah yang sering berhubungan langsung karena terkait dengan peran dan tanggung jawab masing-masing secara organisasi. Model interaksi tersebut dapat diamati melalui gambar berikut.

\footnotetext{
25 Oleh penduduk local adalah orang-orang yang tidak dikenal asal-usulnya tampil sebagai pahlawan di tengah-tengah hiruk-pikuk konflik Poso. Orang-orang misterius itu merasuk ke dalam kubu kedua belah fihak yang bertikai. Pada saat itu isu yang mengemuka adalah simbol-simbol perbedaan agama (Islam dan Kristen). Setelah perseteruan kedua ummat yang berbeda itu mulai jenuh, teroris bermaksud untuk menampilkan ummat Hindu ke dalam arena konflik dengan cara membakar sebuah Pura Agung di Desa Toini, Poso Pesisir pada 10/03/2006. Akan tetapi provokasi itu tidak lagi direspon secara membabi buta oleh masyarakat setempat.
} 


\section{Gambar Struktur Anatomi Jejaring Terorisme Lokal Poso}

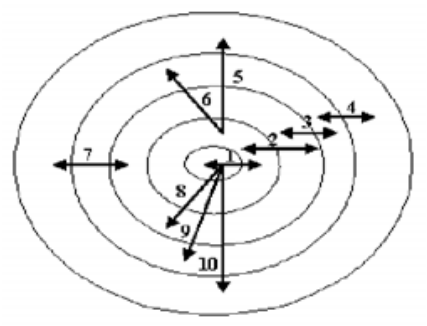

Keterangan:

1 = hubungan timbal-balik pimpinan dengan kader aktif

$2=$ hubungan timbal-balik kader aktif dengan pendukung aktif

3 = hubungan timbal-balik pendukung aktif dengan pendukung pasif

4 = hubungan timbal-balik pendukung pasif dengan simpatisan

$5=$ hubungan satu arah kader aktif terhadap simpatisan

$6=$ hubungan satu arah kader aktif terhadap pendukung pasif

7 = hubungan timbal-balik pendukung aktif dengan simpatisan

$8=$ hubungan satu arah pimpinan terhadap pendukung aktif

$9=$ hubungan satu arah pimpinan terhadap pendukung pasif

$10=$ hubungan satu arah pimpinan terhadap simpatisan

\section{Gambar Struktur Anatomi Jejaring Terorisme Ekstra Lokal Sulawesi Tengah}

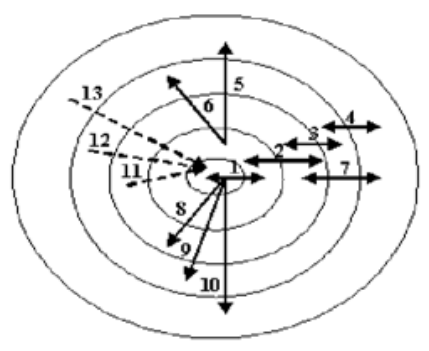

\section{Keterangan:}

$1=$ hubungan timbal-balik pimpinan dengan kader aktif

$2=$ hubungan timbal-balik kader aktif dengan pendukung aktif

3 = hubungan timbal-balik pendukung aktif dengan pendukung pasif

$4=$ hubungan timbal-balik pendukung pasif dengan simpatisan

5 = hubungan satu arah kader aktif terhadap simpatisan

$6=$ hubungan satu arah kader aktif terhadap pendukung pasif

7 = hubungan timbal-balik pendukung aktif dengan simpatisan

$8=$ hubungan satu arah pimpinan terhadap pendukung aktif

$9=$ hubungan satu arah pimpinan terhadap pendukung pasif

$10=$ hubungan satu arah pimpinan terhadap simpatisan

11 = hubungan tidak langsung satu arah pendukung aktif terhadap pimpinan

$12=$ hubnugan tidak langsung satu arah pendukung pasif terhadap pimpinan

13 = hubungan tidak langsung satu arah simpatisan terhadap pimpinan 
Meskipun demikian, wacana keterhubungan teroris Poso dengan terorisme global baru pada tingkat asumsi, sebab belum dilakukan triangulasi data sebagai bentuk validasi dua arah.

Sebagai hasil pengembangan model jejaring yang khas pada organisasi terorisme lokal Poso (Gambar 4) dan ekstra lokal (Gambar 5), jejaring terorisme yang lebih luas yang mencakup nasional dan global digambarkan sebagai berikut.

Gambar Struktur Anatomi Jejaring Lokal Poso dan Ekstra Lokal Sulteng serta Perkiraan Hubungan Jejaring Nasional dan Global

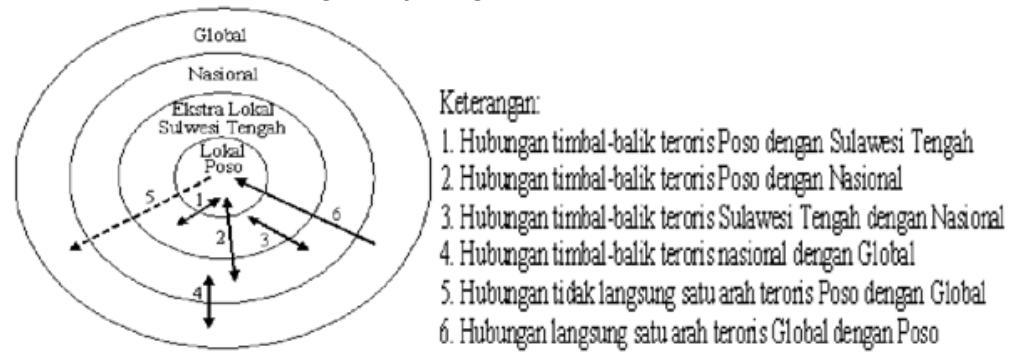

Mengacu pada pengembangan informasi dan pengamatan di lapangan, indikasi keterkaitan dan keterhubungan teroris Poso dengan terorisme nasional dan juga global ditandai oleh beberapa hal, antara lain (1) pasokan logistik berupa dana dan peralatan teror, (2) transformasi kader dari lokal ke nasional hingga global, (3) kemiripan isu dan kelompok yang bersifat fundamental-radikal, dan (4) sejumlah indikator karakteristik kader tentang spirit perjuangan.

\section{Refleksi}

Studi terorisme yang sudah dilakukan selama dua tahun ini telah menemukan tiga hal pokok yang mewarnai terorisme Sulawesi Tengah yang berpusat di Poso yakni (1) spirit ideologis yang menggerakkan para teroris adalah bersifat dogmatis religius, sehingga tampak sebagai gerakan fundemental-radikal atau ekstrim kanan; (2) obsesi perjuangan yang diusung adalah amal ma'ruf nahimungkar yaitu slogan islamis untuk menumpas segala bentuk kejahatan, yang oleh versi mereka bahwa kekuasaan (pemerintah) merupakan pihak yang paling bertanggung jawab, dan (3) terorisme Poso merupakan bagian dari terorisme nasional dan global yang saling terkait melalui jejaring yang kompleks.

Ketiga temuan di atas belum sepenuhnya menggambarkan eksistensi terorisme Poso secara komprehensif. Sebab, faktor-faktor lain 
khususnya mengenai (1) bagaimana peran lingkungan yang terbentuk dan/atau dibentuk sehingga menciptakan habitat yang mengkondisikan serta memfasilitasi aktivitas terorisme, dan (2) bagaimana dukungan finansial yang mendukung aktivitas teroris dalam melakukan pergerakan/perjuangan serta faktor-faktor survive selama lebih dari sepuluh tahun. Kelima faktor tersebut (tiga yang sudah ditemukan dan dua yang belum ditemukan) dapat mengukuhkan teori tentang keunikan terorisme lokal di Indonesia dan kemiripannya dengan teori tentang terorisme lokal di negara lain, serta teori tentang terorisme universal. Selain itu, juga dapat pula disintesiskan mekanisme pergerakan emosi ke tindakan melalui spirit untuk diarahkan pada pengembangan teori "psikososiologis".

\section{E. Kesimpulan}

Proses keterlibatan seseorang dalam terorisme khususnya teroris di Poso merupakan hasil pergerakan mekanisme psikososiologis akibat konflik yang pernah terjadi. Dampak konflik terhadap para keluarga korban yang berupa pengalaman tragis dan sangat mengganggu kestabilan psikologis (aversif), merupakan kondisi potensial bagi individu yang bersangkutan dan sebagai pintu masuk bagi terorisme untuk rekruitmen calon teroris baru. Melalui kondisi labil tersebut, seseorang diorientasikan secara dogmatis religius untuk menancapkan ideologi perjuangan yang menggerakkan semangat (spirit) agar melakukan segala tindakan kekerasan. Di dalam proses tersebut, teridentifikasi dedikasi dan integritas individu calon teroris berdasarkan kapasitasnya, yang kemudian menempatkannya ke posisi lapisan yang pas dalam kelompok terorisme.

Obsesi perjuangan adalah berupa isu-isu yang ditancapkan dalam diri seorang calon teroris untuk membangkitkan heroisme yang kelak akan menjadikannya teroris sejati. Misalnya, pengakuan (semu) diberikan kepada seorang sebagai pahlawan yang telah diorientasikan secara religius menjadi mujahidin untuk memperhalus makna dan esensi perjuangannya hingga diyakininya sebagai ibadah berikut bayangan tentang keindahan syurga $^{\mathbf{2 6}}$ sebagai obsesi pada kehidupan akhirat. Sedangkan obsesi perjuangan dunia menuju syurga yang disebutnya sebagai amal ma'ruf

\footnotetext{
${ }^{26}$ Antara lain kata mereka: Allah telah menjanjikan 70 bidadari yang akan menjemput kematiannya, kebun-kebuan dan buah anggur, gelas-gelas minuman, gadis-gadis montok yang siap melayani, dan seterusnya (selain telah tersebar di kalangan kader, kata-kata ini sering diucapkan oleh Noordin M.Top kepada rekan-rekannya).
} 
nahimungkar, adalah melawan tatanan mapan, yaitu tatanan formal yang dikendalikan oleh pemerintah yang dinilainya sebagai sumber segala dosa bagi ummat. Korban yang jatuh akibat kebrutalan mereka (yang diyakini sebagai perjuangan) tidak menghalangi tindak kekerasan teroris, sebab semua manusia terlebih dahulu telah diremehkan eksistensinya melalui deprivatisasi dan didehumanisasi.

Organisasi atau struktur anatomi teroris di Poso dapat dilihat dalam dua dimensi, yakni dimensi sistem pelapisan dan dimensi jaringan mikromakro. Dalam dimensi sistem pelapisan, terorisme Poso menyerupai struktur terorisme di tempat lain dimana teroris yang sesungguhnya (pimpinan/anggota aktif = lapis ke-1) dibungkus oleh kader aktif (lapis ke-2) disusul pendudkung aktif (lapis ke-3), pendukung pasif (lapis ke-4), dan simpatisan dalam masyarakat (lapis ke-5) sebagai lapis terluar. Sedangkan dimensi jaringan mikro-makro dapat dilihat pada rangkaian jejaring mikro lokal untuk wilayah Poso dan ekstra lokal untuk wilayah Sulawesi Tengah, serta jejaring makro dalam konteks yang lebih luas yakni nasional dan juga global. Terorisme bukanlah organisasi yang berdiri sendiri dalam lingkungan kita di mana ia beroperasi, tetapi merupakan bagian dari organisasi yang lebih besar.

\section{DAFTAR PUSTAKA}

Anonimous, 2004, Aksi Peledakan Bom di Indonesia. Harian Kompas: $11 / 9 / 2004$.

Anonimous, 2005, Bom Dahsyat Guncang Tentena, 21 Orang Tewas, 53 Terluka. Harian Kompas: 29/5/2005.

Anonimous,2006a, Bom-Bom Meledak di Palu dan Poso. Harian Jawa Pos: $1 / 1 / 2006$.

Anonimous, 2006b, Terorisme: Seorang Tersangka di Tangkap di Poso. Harian Kompas: 11/2/2006.

Anonimous, 2007, Baku Tembak di Poso 10 Tewas. Harian Fajar: 23/01/2007.

Anonimous, 2007, Poso Masih Mencekam. Harian Kompas: 23/01/2007.

Anonimous, 2007, Kelompok Poso Hanya Pelaksana Lapangan, Mereka Diatur dan Dikendalikan Dari Jawa. Harian Kompas: 25/01/2007. 
Anonimous, 2007, Mengenal Tokoh-Tokoh Kunci Penguasa Tanah Runtuh Poso. Harian Jawa Pos: 04/02/2007.

Bandura, A, 1987, Social Foundations of Thought and Action: A Social Cognitive Theory. Englewood, N.J.: Prentice Hall.

Bassiouni, MC, 2003, Terrorism, Low Enforcement, and The Mass Media, dalam Reich, W., ed. Origin of Terrorism, terj. Sugeng Haryanto. Jakarta: Muria Kencana.

Clark, R, 1983, 'Pattern in the Lives of ETA Members;, Journal of Terrorism. Vol.4 No.3: 423-54.

Crenshaw, M, 2003a, Logika Terorisme: Perilaku Terorisme Sebagai Hasil Pilihan Strategis, dalam Reich, W, ed. Origin of Terrorism, terj. Sugeng Haryanto, Jakarta: Muria Kencana.

Crenshaw, M, 2003b, Pertanyaan yang Harus Dijawab, Riset yang Harus Dikerjakan, Pengetahuan yang Harus Diterapkan, ed. Reich, W, Origin of Terrorism, terj. Sugeng Haryanto, Jakarta: Muria Kencana.

DeNadro, J, 1986, The Political Strategy of Protest and Rebellion. Princeton NJ: Princeton University Press.

Faisal, Sanapiah, 2003, Filosofi dan Akar Tradisi Penelitian Kualitatif, dalam Analisis Data Penelitian Kualitatif, ed. Burhan Bungin., Jakarta: Rajawali Press.

Gurr, T.R, 2003, Terorisme dalam Demokrasi: Basis Sosial dan Politik, ed. Reich, W, Origin of Terrorism, terj. Sugeng Haryanto, Jakarta: Muria Kencana.

Heskin, K, 1984, The Psychology of Terrorism in Ireland, Annual Review of Social and Personality Psychology, Vol. 9. No. 42:311-80.

Kellen, K, 2003, Ideologi dan Pemberontakan: Terorisme di Jerman Barat, ed. Reich, W, Origin of Terrorism, terj. Sugeng Haryanto, Jakarta: Muria Kencana.

Miles, M.B \& Huberman A.M, 1992, Analisis Data Kualitatif, terj. Tjetjep R.R, Jakarta: Universitas Indonesia Press.

Post, J.M, 1984, 'Notes on Psychodynamic Theory of Terrorism Behavior' Journal of Terrorism. Vol. 7, No.3:241-56. 
Post, J.M, 1986, Hostilite Fraternite: The Group Dynamics of Terrorist Behavior, International Journal of Group Psychotherapy, Vol. 36, No.2: 211-24.

Post, J.M, 2003, Psikologika Teroris: Perilaku Teroris Sebagai Hasil Tekanan Psikologis, ed. Reich, W, Origin of Terrorism, terj. Sugeng Haryanto, Jakarta: Muria Kencana.

Pruitt, D.G, \& Rubin, J.Z, 1986, Social Conflict: Escalation, Stalemate, and Settlement. New York: McGraw-Hill, Inc.

Reich, W, ed. 2003. Origin of Terrorism, terj. Sugeng Haryanto, Jakarta: Muria Kencana.

Sangadji, Ariyanto, 2007, dalam: Metro Realitas, Pemberitaan Metro TV, 25/01/2007.

Suradji, Adjie. 2005. Terorisme. Jakarta: Pustaka Sinar Harapan.

Sutanto, 2006, Pemberantasan Teroris. Harian Kompas: 9/2/2006. 